\title{
Shigellosis in children less than five years in urban slum area: a study at primary health care in Jakarta
}

\author{
Junita Elvira, Agus Firmansyah, Arwin A.P. Akib
}

\begin{abstract}
Background Shigellosis has a global distribution especially in countries with poor hygiene and sanitation. The most common manifestation of shigellosis in children is diarrhea with broad spectrum manifestations from watery diarrhea to classical dysentery. Appropriate antibiotic management is important to eradicate Shigella spp.

Objective To find out shigellosis prevalence and manifestations and also Shigella spp. resistance pattern in children less than 5 years with acute diarrhea in certain district urban slum areas in Jakarta.

Methods This cross sectional study involved 475 outpatients of less than 5 years old with acute diarrhea who visited primary health cares in Jakarta from July- October 2005. Stool for culture and antibiotic resistance test was taken with single rectal swab.

Results Shigella spp. was found only in $3(0.6 \%)$ patients. The subjects were between 6 to 24 months. Watery diarrhea was found in 1 subject and so was the classical dysentery manifestation of fever and bloody diarrhea. Two strains were found, 2 cases of S. sonnei and 1 case of S. flexneri. They were resistance to cotrimoxazole, tetracycline, and colistine.

Conclusion Shigella spp. was not the main cause of acute diarrhea in children less than 5 years old. Due to the small number of cases, we could not find the most common manifestation and resistance pattern of shigellosis in these children. [Paediatr Indones 2007;47:42-46].
\end{abstract}

Keywords: shigellosis, children, clinical manifestation, antibiotic resistance

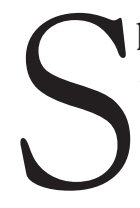

higellosis continues to be a major public-health problem and remains endemic in many developing countries. Shigella spp. causes acute and debilitating diarrhea in young children worldwide. ${ }^{1-3}$ In developing countries where affected populations are immuno-compromised by poor nutrition and infections, deaths attributed to shigellosis are common. Shigella spreads by fecal oral route and the most common mode is person-to-person spreading. Four strains are recognized. S. sonnei and S. boydii are usually associated with short-mild illness with watery or bloody stool. ${ }^{1,2}$ Shigella flexneri is generally more severe, lasts longer, and more common with bloody diarrhea. This strain remains the leading cause of shigellosis in most developing world. $1,4,5$ The last is S. dysentriae which causes the most severe complication such as hemolytic-uremic syndrome with a high mortality rate. 2,4,6

Epidemiological changes and resistance problem of Shigella spp. have been documented in the last two decades of $20^{\text {th }}$ century. ${ }^{1,7}$ Significant changes have occurred. It is very important to reevaluate the issue about shigellosis as an emerging diseases, its clinical manifestations in children especially less than 5 years, and its resistance pattern to various antibiotic in urban slum areas in Jakarta. The purpose of this study was to find out the shigellosis proportion and manifestations as well as Shigella spp. resistance pattern in children

From the Department of Child Health, Medical School, University of Indonesia, Jakarta, Indonesia

Reprint request to: Junita Elvira, MD, Department of Child Health, Medical School, University of Indonesia, Cipto Mangunkusumo Hospital, Jakarta, Indonesia. Tel. 62-21-3907742. Fax. 62-21-3907743. 
Elvira Junita et al: Shigellosis in children less than five years in Jakarta

less than 5 years with acute diarrhea in certain district urban slum areas in Jakarta.

\section{Methods}

This cross sectional study was conducted at 4 certain urban slum areas in Jakarta consisted of Johar Baru, Senen, Kemayoran, and Tebet Primary Health Cares (PHC) from July to October 2005. The sample size was calculated using single formula with shigellosis prevalence estimation of $5 \% .^{3}$ A total of 475 subjects aged 0-59 months with diarrhea less than 7 days whether watery or bloody were included in this study. All of the subjects hadn't received any antibiotic and without any complication. All the parents signed informed consent. The Committee for Medical Research Ethics of the Faculty of Medicine, University of Indonesia approved this study.

Caregivers were interviewed about history of the diseases such as fever, vomiting, abdominal pain, tenesmus, dehydration symptoms, passage and characteristics of stools (frequency, consistency, and color). Physical examination was performed to confirm diagnosis and nutritional status was determined based on actual weight to ideal body weight percentage by National Center of Health Statistic standard. Degree of dehydration was determined based on the WHO standard.?

Stool specimens were taken by single rectal swab using a sterile cotton then were inserted into the Amies media (transport medium package, Trans Bact $\left.{ }^{\circledR}\right) .2,8$ The transport mediums were placed in the container (temperature of $20-30{ }^{\circ} \mathrm{C}$ ) while being transferred to the laboratory of Clinical Pathology Department of Cipto Mangunkusumo Hospital. Stool specimens were cultured for Shigella on SalmonellaShigella agar. Suspected Shigella colony was identified biochemically by standard methods then serologically grouped by a slide agglutination test with commercial antiserum and examined for antibiotic resistancy by standard method. ${ }^{8}$ Data from completely filled forms were processed using computer program SPSS 10.

\section{Results}

Four hundred seventy five children with acute diarrhea aged $0-59$ months were joined in the study
Table 1. Characteristics of subjects with acute diarrhea

\begin{tabular}{lc}
\multicolumn{1}{c}{ Characteristics } & $\mathrm{n}(\%)$ \\
\hline Primary health care area & \\
$\quad$ Johar Baru & $204(42.9)$ \\
Senen & $118(24.8)$ \\
Kemayoran & $62(13.1)$ \\
Tebet & $91(19.2)$ \\
Age (months) & \\
$0-5$ & $50(10.5)$ \\
$6-11$ & $122(25.7)$ \\
$12-35$ & $229(48.2)$ \\
$36-59$ & $74(15.6)$ \\
Sex & \\
Male & $272(57.3)$ \\
Female & $203(42.7)$ \\
Nutritional status & \\
Well nourished & $264(55.6)$ \\
Undernourished & $208(43.8)$ \\
Severe malnutrition & $3(0.6)$ \\
\hline
\end{tabular}

during July-October 2005. These children were ambulatory patients from $4 \mathrm{PHC}$ working areas of Johar Baru, Senen, Kemayoran, and Tebet. Most of the subjects who lived in urban slum areas in those districts belonged to middle-low socio-economic status. The complete characteristics of the subjects are shown in Table 1.

Fever was the most common manifestation that accompanied the diarrhea while vomiting was less frequent $(66.3 \%$ vs. $32.8 \%)$. Abdominal pain and tenesmus were only found in subjects aged $36-59$ months (74 children). We found 24 of them suffered from abdominal pain and 11 with tenesmus. Bloody diarrhea was only found in 12 children $(2.5 \%)$. Classical dysentery manifestations with fever, abdominal pain, tenesmus, and bloody diarrhea were found in 9 children.

Enteric-pathogen bacteria were positive in 4 specimens $(0.8 \%)$ consisted of 3 Shigella spp. specimens and 1 enteropathogen E. coli (EPEC) specimen. Shigellosis prevalence in children less than 5 years was only $0.6 \%, 1$ case came from Johar Baru and 2 from Senen. Stools specimen in subject A was taken on fourth day of diarrhea. The passage of stool was less frequent and only consisted of blood and mucous. From history of illness, there was watery diarrhea at the first day. The dysentery clinical manifestation was only found in subject $A$, the oldest subject. The consistency was very different from that of subject $\mathrm{C}$ which was watery and caused moderate dehydration. Shigellosis manifestations are shown in Table 2. 
Elvira Junita et al: Shigellosis in children less than five years in Jakarta

Table 2. Clinical manifestations of Shigella spp subject

\begin{tabular}{|c|c|c|c|}
\hline & Subject A & Subject B & Subject C \\
\hline Area & Johar Baru & Senen & Senen \\
\hline Age (months) & 24 & 14 & 6 \\
\hline Nutritional status & undernourished & undernourished & undernourished \\
\hline \multicolumn{4}{|l|}{ Manifestation } \\
\hline o Fever & + & + & + \\
\hline o Vomiting & - & - & - \\
\hline o Feses color & yellow & yellow & yellow \\
\hline o Consistency & mucous \& blood $(+)$ & loose, mucous (+) & watery, mucous (+) \\
\hline o Frequency & $\geq 10$ times/day & $\geq 10$ times/day & 4-9 times/day \\
\hline - Dehydration status & $(-)$ & $(-)$ & moderate \\
\hline
\end{tabular}

Table 3. Shigella spp strain and resistance pattern

\begin{tabular}{lccc}
\hline \multicolumn{1}{c}{ Subject } & A & B & C \\
\hline Strain & Shigella sonnei & Shigella sonnei & Shigella flexneri \\
Sensitivity & & & - \\
- Ampicillin & + & + & - \\
- Amoxicillin & + & + & + \\
- Nalidixic acid & + & + & + \\
- Chloramphenicol & + & + & + \\
- Cefixime & + & + & - \\
- Cephalotine & + & + & + \\
- Cyprofloxacin & + & - & - \\
- Colistine & - & - & - \\
- Tetracycliine & - & - & - \\
- Co-trimoxazole & - & + & - \\
\hline
\end{tabular}

Shigella spp. specimen culture revealed two strains consisted of 2 S.sonnei and 1 S. flexneri. S. flexneri showed resistance to more numbers of antibiotics than S.sonnei. Both of them were resistance to co-trimoxazole, tetracycline, and colistine but were still sensitive to nalidixic acid, chloramphenicol, cefixime, and ciprofloxacin (Table 3).

\section{Discussion}

Previous epidemiological studies were performed on medical record data in which the clinical manifestations were recorded well and the stool culture was done routinely. The duration of studies was long enough within wide area and better method to get local strain pattern, resistance pattern, and climate preference.

Several studies also showed similar results. Ashkenazi et al ${ }^{9}$ revealed the prevalence of shigellosis in adults and children in Israel was 5.8\% from 51,300 stools culture performed during a 6 -year period. This number seems not far from the study of Subekti et $\mathrm{al}^{3}$ which showed $5 \%$ of 3,848 children and adult patients from 8 hospitals in 7 provinces in Indonesia. ${ }^{3}$ Thisyakorn et al ${ }^{6}$ needed 5-year study to collect 230 children with positive stool cultures for Shigellla. Batthiki et a ${ }^{10}$ reported the prevalence of shigellosis in Jordan was only $0.13 \%$ of 34,529 isolates. Lee et $\mathrm{al}^{11}$ reported that they had to review for almost 10 years in order to collect 386 (1.4\%) Shigella isolates from 26,320 children stools culture in an urban community in Malaysia.

This study was a community-based study to identify shigellosis burden in small number of children less than 5 years in restricted urban slum areas in Jakarta due to fund and time limitations. In this study shigellosis prevalence was only $0.6 \%$ compared to other studies in Indonesian children where shigellosis accounted for $17.8-30 \% . .^{12,13}$ Most studies conducted in developing countries showed that stool culture may only identify $37-55 \%$ Shigella of those suspected shigellosis. ${ }^{14}$ Even in the developed countries such as United State of America, one study showed that stool culture was insensitive in identifying bacterial 
enteropathogen. ${ }^{15}$ Thiem et al ${ }^{16}$ supported this statement by reconfirming the culture by PCR and detected $36 \%$ of culture-negative patients were PCR confirmed shigellosis.

Shigellosis clinical manifestations may vary from asymptomatic to severe dysentry with several complications. Huskin et $a l^{17}$ described that there was significant difference between shigellosis manifestations in infants and children. Infants were more common to have a history of non bloody diarrhea, moderate to severe dehydration, or bacteremia, but less common to have fever. Subekti et $\mathrm{al}^{3}$ found that abdominal pain and vomiting were two major symptoms in shigellosis. Stool consisted of mucous and blood was only found in 27\% cases. Dwipoerwantoro et $\mathrm{al}^{18}$ found that shigellosis manifestations in children was unspecific; $67 \%$ of those were without fever, $92 \%$ without tenesmus and $96 \%$ with watery diarrhea. It was different with that found by Thisyakorn et al. ${ }^{6}$ Their study revealed that watery diarrhea only accounted for $11.9 \%$ of shigellosis cases. Unfortunately, we could not get a better picture of shigellosis manifestations in children less than 5 as only 3 subjects with stool confirmed shigellosis in this study.

From shigellosis clinical manifestations, we could not map the Shigella strain distribution in this study. We only found 2 most common Shigella strains, which were S. sonnei and S. flexneri. These strains were reported from several studies, S. sonnei was commonly reported from the developed countries ${ }^{9,15,19}$ and $S$. flexneri was found in a large portion in developing countries. ${ }^{3-6,11,16-18}$ Lee at al ${ }^{11}$ reported that there was shifting strain distribution in the last 5-year study in Malaysia, the number of S. flexneri positive culture decreased. S. flexneri caused more severe illness in the youngest subject (6 months old) with watery diarrhea and moderate dehydration in this study.

Both of S. sonnei strains in this study were still susceptible to ampicillin and amoxicillin. Subekti et $a^{3}$ stated that only $23 \%$ of S. sonnei were resistance to ampicillin in Indonesia, while some studies reported that ampicillin and amoxicillin were no longer effective for the treatment of shigellosis. ${ }^{18,20-25}$ Resistance to much more antibiotics was showed by S.flexneri in this study.

In summary, our study shows that Shigella spp. is not the main cause of acute diarrhea in children less than 5 years. Due to small number of cases, we cannot find out the most common manifestations and the resistance pattern of shigellosis. We suggest that laboratory for culture study is placed in the working area to avoid any inoculation delay and to make it easier to observe. ${ }^{2,8}$

\section{References}

1. Legros D. Shigellosis: report of workshop. J Health Popul Nutr 2004;22:445-9.

2. Clemens J, Kotloff K, Kay B. Generic protocol to estimate the burden of Shigella diarrhoea and dysenteric mortality. Geneva: WHO; 1999. p. 5-37.

3. Subekti D, Oyofo BA, Tjaniadi P, Corwin AL, Larasati W, Putri M, et al. Shigella spp. surveillance in Indonesia: the emergence or reemergence of S.dysenteriae. Emerg Infect Dis 2000;7:137-40.

4. Richard LM, Bennish ML Salam MA. The management of bloody diarrhoea in young children. Cited 2002 May 20. available from: url: http://www.who.int/child-adolescenthealth/ New_Publications / Child_Health / WHO_CDD -94.49. htm.

5. Huilan S, Zhen LG, Mathan NM, Mathew MM, Olarte J, Esperjo R, et al. Etiology of acute diarrhoea among children in developing countries: a multi-center study in five countries. Bull World Health Organization 1991;69:549-55.

6. Thisyakorn U, Rienprayoon S. Shigellosis in Thai children: epidemiologic, clinical and laboratory features. Pediatr Infect Dis J 1992;11:213-5.

7. World Health Organization. The treatment of diarrhea: a manual for physicians and other senior health workers. WHO/CDD/SER/80.2 rev.3. Geneva: World Health Organization; 1995.

8. Vandepitte J, Engbaek K, Piot P, Heuck CC. Basic laboratory procedures in clinical bacteriology. Geneva: WHO; 1991. p. 37-8, 103-5.

9. Ashkenazi S, May-Zahav M, Dinari G, Gabbay U, Zilberberg R, Samra Z. Recent trends in the epidemiology of Shigella species in Israel. Clin Infect Dis 1993;17:897-9.

10. Batthikhi MN. Bloody diarrhoea cases caused by Shigella and amoeba in Jordan. New Microbiol 2004; 27:37-47.

11. Lee WS, Puthucheary SD. Species distribution and antibiotic resistance of Shigella isolates in an urban community in Malaysia. Med J Malaysia 2003; 58:262-7.

12. Aryani A. Gambaran diare akut serta hubungannya dengan gejala yang ditemukan pada anak 0-2 tahun yang dirawat di SMF anak RSCM periode September 1996 - Januari 1997 
(Tesis). Jakarta: Universitas Indonesia; 1998.

13. Departemen Kesehatan RI. Epidemiologi dan etiologi diare. In: Ditjen PPM \& PLP DepKes, editors. Buku ajar diare. Jakarta: Depkes; 1999. p. 3-16.

14. Clinical update: shigellosis. A supplement to Issue no 44, 1991. Dialogue on Diarrhoea Online. cited 2002 May 20. available from: url: http://www.rehydrate.org/dd/su44.

15. Slutsker L, Ries AA, Greene KD, Wells JG, Hutwagner L, Griffin PM. Escherichia coli O157: H7 diarrhea in the United States: clinical and epidemiologic features. Annals Intern Med 1997;126:505-13.

16. Thiem VD, Scthabutr O, von Seidlein L, Tung TV, Canh DG, Chien BT, et al. Detection of Shigella by a PCR assay targeting the ipaH gene suggest increased prevalence of shigellosis in Nha Trang, Vietnam. J Clin Microbiol 2004;42:2031-5.

17. Huskins WC, Griffiths JK, Faruque ASG, Bennish ML. Shigellosis in neonates and young infants. J Pediatr 1994;125:14-22.

18. Dwipoerwantoro PG, Pulungsih SP, Susanti NI, Sadikin H, Firmansyah A. A study on the antibiotic resitance of Shigella. Pediatr Indones 2005;45:49-54.

19. Schulze S. Broward County study shows increase in Shigella cases. cited 2006 February 18. available from: url: http:// www.doh.state.fl.us/ Disease_ctrl/epi /Epi_Updates / Epi_ Weekly 107-25-03.htm.

20. Bennish ML, Salam MA, Hossein MA, Myaux J, Haque B, Chakraborty J. Antimicrobial resistance among Shigella isolates in Bangladesh, 1983-1990: increasing frequency of strains multiply resistant to ampicillin, trimethoprimsulfamethoxazole, and nalidixic acid. Clin Infec Dis 1992;14:1055-60.

21. Kim S, Kim J, Kang Y, Park Y, Lee B. Occurrence of extendedspectrum beta-lactamases in members of the genus Shigella in the Republic of Korea. J Clin Microbiol 2004;42:5264-9.

22. Schmuacher H, Nir M, Mansa B, Grassy A. Beta-lactamases in Shigella. APMIS 1992;100:954-6.

23. Sack RB, Rahman M, Yunus M, Khan EH. Antimicrobial resistance in organisms causing diarrheal disease. Clin Infect Dis 1997;24 Suppl 1:S102-5.

24. Putnam SD,Riddle MS, WierzbaTF, Pittner BT, Elyazeed RA, El-Gendy A, et al. Antimicrobial susceptibility trends among Escherichia coli and Shigella spp. isolated from rural Egyptian pediatric populations with diarrhoea between 1995 and 2000 . Clin Microbiol Infect 2004;10:804-10.

25. Vasilev V, Japheth R,Yishai R, Andorn N. Antimicrobial resistance of Shigella flexneri serotypes in Israel during a period of three years: 2000-2002. Epidemiol Infect 2004;132:1049-54. 